Management Dynamics

Vol. 23, No. 2: 33-44, 2020

Shanker Dev Campus

Doi: https://doi.org/10.3126/md.v23i2.35804

\title{
Impact of Relationship Marketing on Customer Retention in Higher Education
}

\author{
Sajeeb Kumar Shrestha* \\ https://orcid.org/0000-0002-5227-771X
}

\begin{abstract}
This research attempts to measure the impact of relationship marketing on customer retention in higher education. Exploratory cum descriptive and causal research design was used. Sources of data are students, parents, and faculties of different colleges. A convenient sampling method was used for sample selection. Structured questionnaires were used for collecting responses. Primary cross-section data were collected. PLS-SEM was used for testing the psychometric and econometric properties of the model. This research confirmed that relationship marketing, customer orientation, customer satisfaction, and customer retention are possible in the academic sector. Policymakers and academic experts should focus on relationship marketing factors and customer orientation to enhance customer satisfaction and customer retention.
\end{abstract}

Keywords: Relationship marketing, Customer orientation, Customer Satisfaction, Customer Retention, PLS-SEM.

\section{Introduction}

Marketing techniques have progressed from "transactional" to "relationship" marketing over the last four decades. Yesterday's business model promoted retail marketing, mass manufacturing, and standardized goods and services. Companies that still depend on this obsolete model would fall behind the competition (Berry, 1995). There are many reasons for this growth, but these include increasingly sophisticated and educated clients, rapid changes in technologies, increased competition, and decreasing product differentiation in the global business climate. The underlying notion behind relationship marketing is that the degree of satisfaction of stakeholders with their relationship greatly, not just the goods or services.

The business climate today continues to evolve and is becoming more volatile. In this context, Weinstein and Johnson (2003) suggest that at least two-thirds of the marketing effort in a company should concentrate on customer acquisition by establishing and maintaining good ties with customers. Relationship marketing uses a series of connected events to retain the customer. The longer a company retains its clients, the more profitable it gets from predictable

* Dr. Shrestha is Associate Professor at Tribhuvan University, Faculty of Management, Shanker Dev Campus. E-mail:drsajeeb@gmail.com 
customer buying, lower business costs, client referrals, consumers' willingness to pay price premiums, and lower customer purchasing costs. A new customer costs up to five times more than a current one (Weinstein \& Johnson, 2003). The value of retaining customers is that there is consistent proof of customer retention and profitability. It seems like the longer the relations of seller/manufacturer remains, the higher the probability of further business with them, even to the point of a single source.

The main principles of designing marketing campaigns are consumer satisfaction and customer loyalty. Successful and creative businesses increase their efforts to track and enhance satisfaction, as they know how critical these practices are to increase their image, understand their customers and increase their income (Hennig et al., 2002). Much like school, the happiness of the student can have a very significant effect on future behavior. Some research has been performed in the last 20 years to assess student satisfaction (Betz et al., 1971; Guo, 2010; Mangano \& Zhao, 2013; Morgan, 2000).

Customer satisfaction and retention is the primary objective of relationship marketing and often even the relationship marketing term itself (Sheth \& Parvatiyar, 1995). Customer repeat purchase behavior and customer word-of-mouth communication are key components of customer loyalty, satisfaction and retention (Hennig et al., 2002).

\section{Literature Review and Theoretical Framework}

Relationship marketing appeared in the 1980s when it was recognized that many trade groups were relational by nature, especially in the service industry (Berry, 1983; Dwyer, 1987; Gronroos, 1999; Gummesson, 2002; Sheth \& Parvatiyar, 2000). Marketing relationships emerged as an alternative to the prevailing view of marketing as a series of transactions in the 1980s since many trade relationships, particularly in the service industry, became known to be connected by nature (Berry, 1983; Dwyer, 1987; Gronroos, 1997; Gummesson, 2002; Sheth \& Parvatiyar, 2000). Relationship marketing' concerns customer relationships attraction, growth and retention (Berry \& Parasuraman 1991; Colgate \& Dahaer, 2000; Storbacka et al., 1994).

Commitment is described as a process of adaptation that is the product of the parties' intentions to act and their positive attitude (Storbacka et al., 1994). The continuity of the relationship between exchange parties is implied or explicit. It is the most important factor for effective customer relations (Morgan \& Hunt, 1994; Wetzels et al., 1998). Commitment is the basis for establishing relationships (Berry \& Parasuraman, 1991) and is a key to establishing relationships (Knapp \& Taylor, 1994). If there is no engagement, the relationship ends (Grossman, 1999; Lund, 1985). It is a psychological feeling of the mind, which shapes an attitude to continue a relationship with a business partner (Grossman, 1999).

Trust is ready to count on an exchange partner with whom you trust (Armstrong \& Seng, 2000). The conviction is that the word or promise is trustworthy, and a party fulfills its partnership obligations (Schurr \& Ozanne, 1985). Trust is based on experience, so that the more encounters a customer has with a company, the more confident it is (Grossman, 1999). 
Trust is an important part of sustaining relationships (Butler, 1986). Rempel et al. (1985) suggested three factors of trust as predictability, dependability, and faith. Rempel et al. (1985) suggest that confidence consists of three elements: predictability, dependability, and faith.

Social bond is the degree of personal true buyer-seller interaction (Wilson, 1995). It is the effective and emotional psychological co-operation component. It involves friendship, familiarity, and trust created by interpersonal interaction. It becomes a personal bond (Rodriguez \& Wilson, 2002). Structural bond is the real bond where businesses offer structural and infrastructural support to consumers or customers.

Customer orientation is the proactive approach to make aware of customer needs and the company's attempt to adopt the marketing concept (Wiele et al., 2002; Williams \& Naumann, 2011). It assumes that customer satisfaction becomes the predecessor of a company's success (Carson et al., 1998). So, Customer needs and wants are considered while making marketing strategies (Williams \& Naumann, 2011).

Customer satisfaction is the feeling of wellbeing and comfort (Pizam \& Ellis, 1999). It might be short term transactions to long term relationship building. In business to business marketing, customer satisfaction can be seen to foster the parties over the long term (Moller \& Wilson, 1995; Tikkanen \& Alajoutsijarvi, 2002). Company satisfaction can be viewed as a crucial turning point in buyer-seller relations growth (Hennig et al., 2002).

Customer retention means increasing the long term relationship with customers. It becomes comfortable for a company to retain an old customer than to find a new customer ( $\mathrm{O}^{\prime}$ Connell \& Keenan, 1990; Reichheld \& Kenny, 1990). Lu and Seock (2008) posited that marketing should create, sustain, and improve consumer and other parties' relations at a benefit to achieve the aims of the parties. Certain non-economic benefits are improved for consumer trust, commitment engagement, and cooperation (Shantanu, 2005).

Bhandari (2017) examined the impact of relationship marketing practices on customer loyalty in Nepalese commercial banks. The result showed that there is a positive relationship between trust, commitment, conflict handling, and communication with customer loyalty. HennigThurau (2004) depicted that service personnel's customer orientation is often regarded as a major determinant of service firms' success. Customer orientation of service employees has an impact on customer satisfaction and retention (Hennig-Thurau, 2004). Rootman et al. (2011) found that relationship marketing affects customer retention in the banking sector. Bruno-Britz (2008) suggested that customized banking products and services increase customer retention. Datta et al. (2018) measured Bangla food retailing sector and developed a customer retention strategy and conceptual framework. Service quality, trust, bond, and customer satisfaction are vital for creating positive customer loyalty, and creating customer retention (Datta et al., 2018). 
There is a lack of study done in relationship marketing and customer retention in higher education. This study is done to address the main impact of relationship marketing on customer satisfaction led to retain customers in higher education. The research questions of the study are as follows,

What is the impact of relationship marketing on customer orientation?

What is the impact of relationship marketing on customer satisfaction?

What is the impact of customer orientation on customer retention?

What is the impact of customer satisfaction on customer retention?

\section{Figure1: Conceptual Framework}

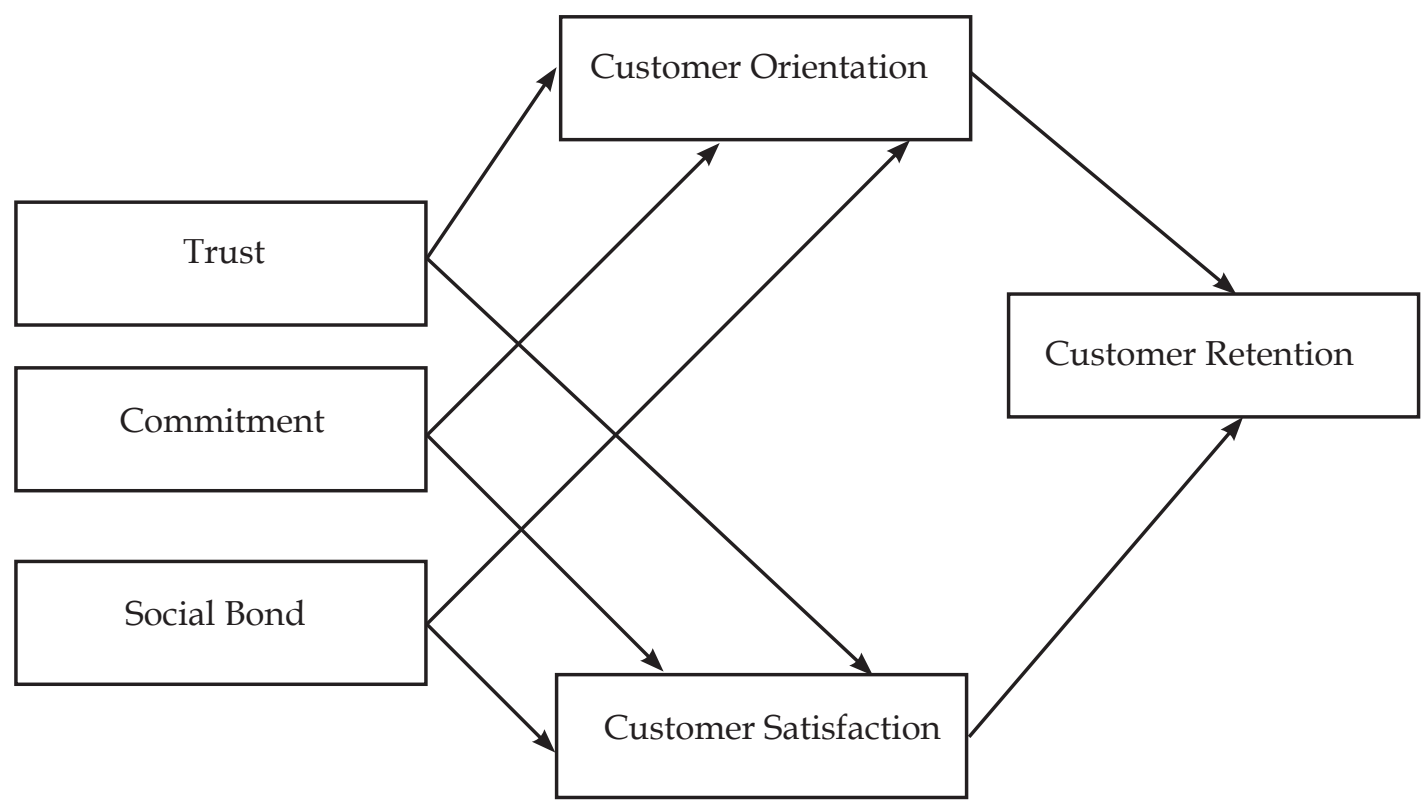

\section{Development of Hypothesis}

H1: Trust influence on customer orientation

H2: Commitment influence on customer orientation

H3: Social bond influence customer orientation.

H4: Trust influence on customer satisfaction.

$\mathrm{H} 5$ : Commitment influence on customer satisfaction

H6: Social bond influence on customer satisfaction.

H7: Customer orientation influence on customer retention.

H8: Customer satisfaction influence on customer retention

\section{Methods}

The descriptive and causal research design was used in this study to achieve research objectives (Malhotra \& Birks, 2006). The literature review was thoroughly done in descriptive 
research, constructs were identified, and analysis was done properly. Causal research tests the hypotheses. The study population was students, faculty, and parents of different colleges teaching higher degrees in Kathmandu City.

Primary cross-section data were collected. Faculties were chosen as current running faculties teaching on the colleges. Students and parents are selected as the students, who paid the college fees within a month during survey time were identified, and through them, their parents were contacted, and the questionnaires were filled and collected. Conveniently other parents and guardians' and faculties' opinions were also collected.

Structured questionnaires were administered based on five-point Likert scale anchoring ' $1=$ Strongly Disagree' to ' $5=$ Strongly Agree'. The questionnaire survey was done to collect responses (Malhotra \& Birks, 2006). Convenient samples were collected, giving research findings to the general public's overall view (Henry, 1990; Kayaman \& Arasli, 2007; Kobayashi, 2011). Two-hundred data were collected for this research, suitable for analysis (Kline, 2011; Cavana et al., 2000; Dillman, 2000).

SEM was used to test the proposed model. SEM evaluates the validity and reliability of the model. PLS-SEM was used bootstrapping of 5000 sub-samples (Hair et al., 2013). Smart PLS 2.0 was used for SEM analysis.

Fifty-seven percent of respondents were male, and 43 percent respondents were female. Sixty percent of respondents were students, 22 percent were faculties, and 18 percent were the students' parents and guardians.

The study's limitation was written in this way. This study is restricted only to Kathmandu city, since for research purposes, Kathmandu is the capital city and central location. This research used primary data.

\section{Results and Discussion}

The study is carried out to assess the effect of relationship marketing in higher education on customer retention. For the partial least square structural equation modeling, Smart PLS 2.0 is used. The model is tested in two stages as an outer or inner model.

The outer model is called the measurement model that validates the reliability and validity of the constructs. The inner model is the structural model that tests the path relationship between the constructs.

Two-stage analysis processes are done for SEM. The measurement model was tested first, and the structural model was tested then (Hair et al., 2014). To evaluate the significance of the path coefficients and loadings, the bootstrapping approach (5000 re-samples) was used (Hair et al., 2014). Smart PLS is a renowned instrument in model structure for the estimation of path coefficients. The PLS technique is clearly popular in marketing and management research, as it can resolve non-normality and small and medium sample sizes (Hair et al., 2014). 


\section{Measurement Model}

The measurement model tests the model's psychometric dimension, including item loadings, Composite Reliability (CR), and Average Variance Extracted (AVE). This is elaborated in Table1.

Table1: Outer or Measurement Model

\begin{tabular}{|c|c|c|c|}
\hline Constructs & $\begin{array}{c}\text { Composite Reliability } \\
\text { (CR) }\end{array}$ & Cronbach's Alpha (a) & AVE \\
\hline Trust & 0.869 & 0.808 & 0.625 \\
\hline Commitment & 0.867 & 0.770 & 0.686 \\
\hline Social Bond & 0.803 & 0.637 & 0.577 \\
\hline Customer Retention & 0.845 & 0.724 & 0.645 \\
\hline Customer Orientation & 0.832 & 0.731 & 0.554 \\
\hline Customer Satisfaction & 0.827 & 0.725 & 0.616 \\
\hline
\end{tabular}

Table 1 expresses, Cronbach's Alpha is greater than 0.7. This means and the constructs are reliable. For validity assessment, CR and AVE were used (Hair et al., 2014). CR should be greater than of threshold value of 0.7; AVE should be more than the cutoff value of 0.5 , and comparing that CR should be greater than AVE (Hair et al., 2014). All these criteria were met, so; Validity of the model is proved (Hair et al., 2014).

\section{Figure 2: Measurement Model (Graph)}

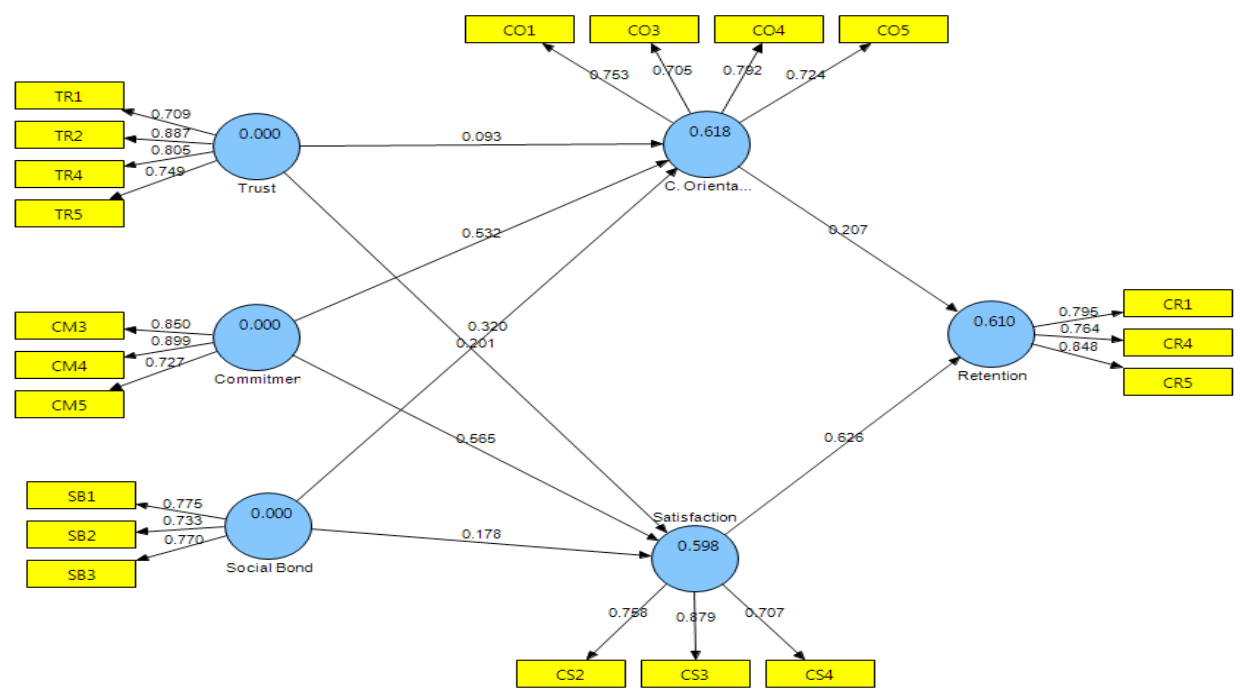

Figure 2 shows that the indicator variable's standard loadings are greater than 0.6 , reliability of the indicators has been verified (Hair et al., 2014). Customer orientation is explained by .618 or 61.8 percent, customer satisfaction by 0.598 or 59.8 percent, and customer retention by .610 or 61 percent. 
The indicators' cross-loadings were also measured and checked for the discriminant validity of the reflective measuring model. Table 2 outlines it.

Table2: Cross Loadings

\begin{tabular}{|c|c|c|c|c|c|c|}
\hline $\begin{array}{c}\text { Scale } \\
\text { Items }\end{array}$ & $\begin{array}{c}\text { Customer } \\
\text { Orientation }\end{array}$ & Commitment & $\begin{array}{c}\text { Customer } \\
\text { Retention }\end{array}$ & $\begin{array}{c}\text { Customer } \\
\text { Satisfaction }\end{array}$ & $\begin{array}{c}\text { Social } \\
\text { Bond }\end{array}$ & Trust \\
\hline CM3 & 0.619 & $\mathbf{0 . 8 5 0}$ & 0.654 & 0.646 & 0.473 & 0.269 \\
\hline CM4 & 0.729 & $\mathbf{0 . 8 9 9}$ & 0.515 & 0.642 & 0.487 & 0.304 \\
\hline CM5 & 0.422 & $\mathbf{0 . 7 2 7}$ & 0.487 & 0.521 & 0.254 & 0.422 \\
\hline CO1 & $\mathbf{0 . 7 5 3}$ & 0.454 & 0.521 & 0.562 & 0.588 & 0.215 \\
\hline CO3 & $\mathbf{0 . 7 0 5}$ & 0.523 & 0.370 & 0.368 & 0.489 & 0.241 \\
\hline CO4 & $\mathbf{0 . 7 9 2}$ & 0.615 & 0.537 & 0.510 & 0.373 & 0.349 \\
\hline CO5 & $\mathbf{0 . 7 2 4}$ & 0.576 & 0.437 & 0.568 & 0.379 & 0.329 \\
\hline CR1 & 0.460 & 0.566 & $\mathbf{0 . 7 9 5}$ & 0.591 & 0.201 & 0.398 \\
\hline CR4 & 0.465 & 0.478 & $\mathbf{0 . 7 6 5}$ & 0.604 & 0.421 & 0.397 \\
\hline CR5 & 0.588 & 0.560 & $\mathbf{0 . 8 4 8}$ & 0.649 & 0.323 & 0.292 \\
\hline CS2 & 0.515 & 0.510 & 0.509 & $\mathbf{0 . 7 5 8}$ & 0.522 & 0.378 \\
\hline CS3 & 0.601 & 0.709 & 0.761 & $\mathbf{0 . 8 7 9}$ & 0.342 & 0.290 \\
\hline CS4 & 0.471 & 0.474 & 0.497 & $\mathbf{0 . 7 0 8}$ & 0.376 & 0.465 \\
\hline SB1 & 0.427 & 0.421 & 0.378 & 0.516 & $\mathbf{0 . 7 7 5}$ & 0.328 \\
\hline SB2 & 0.382 & 0.245 & 0.236 & 0.325 & $\mathbf{0 . 7 3 3}$ & 0.091 \\
\hline SB3 & 0.571 & 0.452 & 0.267 & 0.317 & $\mathbf{0 . 7 7 0}$ & 0.157 \\
\hline TR1 & 0.113 & 0.042 & 0.137 & 0.175 & 0.143 & $\mathbf{0 . 7 0 9}$ \\
\hline TR2 & 0.430 & 0.434 & 0.446 & 0.503 & 0.350 & $\mathbf{0 . 8 8 7}$ \\
\hline TR4 & 0.182 & 0.240 & 0.278 & 0.325 & 0.137 & $\mathbf{0 . 8 0 5}$ \\
\hline TR5 & 0.326 & 0.316 & 0.410 & 0.328 & 0.111 & $\mathbf{0 . 7 4 9}$ \\
\hline
\end{tabular}

Table 2 indicates that the exterior loads are higher than loads for the rows and columns (Hair et al., 2014). There is also proof of legitimacy that is discriminant validity (Hair et al., 2014).

Fornell and Larcker Criterion (1981) is a device of testing discriminant validity. The diagonal line indicates the square root of the construct's AVEs, and it should be greater than the interitem correlation values of the rows and columns construct. In Table 3, it is clarified. 
Table 3: Fornell and Larcker Criterion

\begin{tabular}{|c|c|c|c|c|c|c|}
\hline Constructs & $\begin{array}{c}\text { Customer } \\
\text { Orientation }\end{array}$ & Commitment & Retention & $\begin{array}{c}\text { Customer } \\
\text { Satisfaction }\end{array}$ & $\begin{array}{c}\text { Social } \\
\text { Bond }\end{array}$ & Trust \\
\hline $\begin{array}{c}\text { Customer } \\
\text { Orientation }\end{array}$ & $\mathbf{0 . 7 4 4}$ & 0 & 0 & 0 & 0 & 0 \\
\hline Commitment & 0.7284 & $\mathbf{0 . 8 2 8}$ & 0 & 0 & 0 & 0 \\
\hline Retention & 0.6308 & 0.6656 & $\mathbf{0 . 8 0 3}$ & 0 & 0 & 0 \\
\hline $\begin{array}{c}\text { Customer } \\
\text { Satisfaction }\end{array}$ & 0.6773 & 0.7315 & 0.7661 & $\mathbf{0 . 7 8 5}$ & 0 & 0 \\
\hline Social Bond & 0.6118 & 0.503 & 0.3927 & 0.5146 & $\mathbf{0 . 7 6 0}$ & 0 \\
\hline Trust & 0.3821 & 0.3855 & 0.4471 & 0.4654 & 0.2639 & $\mathbf{0 . 7 9 1}$ \\
\hline
\end{tabular}

Table 3 shows that for each row and each column, diagonal line scores are greater, so discriminating validity is verified, and each construct is different from each other, and the study is sufficient for final review.

\section{Structural Model}

The structural model tests the hypotheses. Variance Based Structural Equation Modeling run the bootstrapping of 5000 resamples and beta value of the constructs, $t$-value, and coefficient of determination $\left(R^{2}\right)$ was achieved. It is explained in Figure 3.

Figure 3: Structural Model

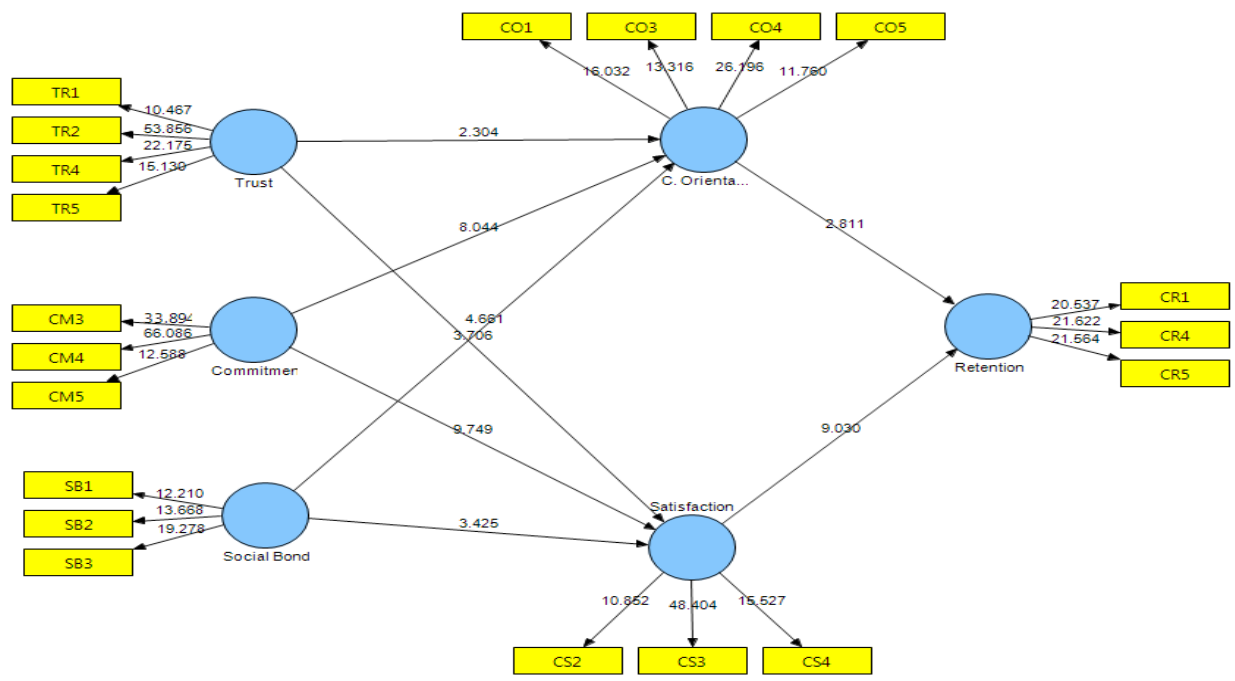


Figure 3 shows items and path coefficients on $t$-values. The relationship between exogenous and endogenous constructs was evaluated at a 5 percent level of significance for path coefficient ( $\beta$ ) and a t-statistics value greater than 1.96 (Hair et al., 2012). Coefficient value is also considered, which explains the model's variation (Henseler et al., 2015). Path coefficients are shown in Table 4.

Table4: Path Coefficients

\begin{tabular}{|l|c|c|c|}
\hline \multicolumn{1}{|c|}{ Path } & Beta & t-value & Decision \\
\hline H1: Trust -> Customer Orientation & 0.093 & 2.304 & Supported \\
\hline H2: Commitment -> Customer Orientation & 0.532 & 8.044 & Supported \\
\hline H3: Social Bond -> Customer Orientation & 0.320 & 4.661 & Supported \\
\hline H4: Trust -> Satisfaction & 0.201 & 3.706 & Supported \\
\hline H5: Commitment -> Customer Satisfaction & 0.565 & 9.749 & Supported \\
\hline H6: Social Bond -> Customer Satisfaction & 0.178 & 3.425 & Supported \\
\hline H7: Customer Orientation -> Customer Retention & 0.207 & 2.811 & Supported \\
\hline H8: Customer Satisfaction -> Customer Retention & 0.626 & 9.030 & Supported \\
\hline
\end{tabular}

Table 4 illustrates the hypothesis testing. It is found the relationship between trust and customer orientation $(\beta=.093$; $t$-value $=2.304)$, commitment and customer orientation $(\beta=.532$; $\mathrm{t}$-value $=8.044)$, social bond and customer orientation $(\beta=.320$; $\mathrm{t}$-value $=4.661)$ are significant, providing support for $\mathrm{H} 1, \mathrm{H} 2$ and $\mathrm{H} 3$.

Similarly, the relationship between trust and satisfaction $(\beta=.201$, t-value=3.706), commitment and satisfaction $(\beta=.565$, $t$-value $=9.749)$, and social bond and customer satisfaction $(\beta=.178$, $\mathrm{t}$-value $=3.425$ ) are significant, thus supporting for $\mathrm{H} 4, \mathrm{H} 5$ and $\mathrm{H} 6$.

Further the relationship between customer orientation and retention $(\beta=.207$, $t$-value $=2.811)$ and satisfaction and customer retention $(\beta=.626$, $\mathrm{t}$-value=9.030) provide support for $\mathrm{H} 7$ and $\mathrm{H} 8$.

\section{Conclusion}

This research is done to measure the impact of relationship marketing on customer retention in higher education. It is found trust; commitment and social bond are the significant predictors of customer orientation. Trust, commitment, and social bond are also significant predictors of customer satisfaction. Customer orientation and customer satisfaction also positively influence customer retention. This study aligns with Hennig-Thurau (2004) that customer orientation of service personnel leads to customer satisfaction and retention. It can be confirmed that there exists a significant positive relationship between relationship marketing, customer orientation, customer satisfaction, and customer retention. This study is consistent with the finding of Bruno-Britz (2008), Datta et al. (2018), and Rootman et al. (2011) that relationship marketing influences customer retention. Due to relationship marketing in a successful organization, customers are always loyal to the organization and happily accept the organization's products and services, which leads to higher customer satisfaction and customer retention. 


\section{References}

Armstrong, R.W, \& Seng, T.B. (2000). Corporate-customer satisfaction in the banking industry of Singapore. International Journal of Bank Marketing, 18(3), 97-111

Berry, L. (1983). Relationship marketing. In L.L. Berry, G.L. Shostack and G.D., Upah (Eds.), Emerging perspectives of service marketing (pp. 25-28). Chicago, IL: American Marketing Association.

Berry, L. (1995). Relationship marketing of services -Growing interest, emerging perspectives. Journal of the Academy of Marketing Science, 23(4), 236-245.

Berry, L., \& Parasuraman, A. (1991). Marketing services: Competing through quality. New York: Free Press.

Betz, E.L., Menne, J.W., Starr, A.M., \& Klingensmith, J.E. (1971). A dimensional analysis of college student satisfaction. Measurement and Evaluation in Guidance, 4(2), 99106, DOI: $10.1080 / 00256307.1971 .12022488$

Bhandari, B. (2017). Relationship marketing and customer loyalty: A study of Nepalese commercial banks. https://ssrn.com/abstract $=3105174$

Bruno-Britz, M. (2008). Reading customers' minds: Predictive analytics tools are helping banks understand customers' behaviour and meet their unique needs with tailored products and services, improving customer retention as a result. Bank Systems and Technology, 45(5), 30.

Butler, J.K. (1986). Reciprocity of dyadic trust in close male-female relationships. The Journal of Social Psychology, 126(5), 579-591. doi:10.1080/00224545.1986.9713630

Carson, D., Gilmore, A., \& Maclaran, P. (1998). Customer or profit focus: An alternative perspective. Journal of Marketing Practice Applied Marketing Science 4(1):26-39

Cavana, R., Delahaye, B.L., \& Sekaran, U. (2000). Applied business research: Qualitative and quantitative methods. Milton Queensland: John Wiley \& Sons Australia Ltd.

Colgate, M.R., \& Dahaer, J. (2000). Implementing a customer relationship strategy: The asymmetric impact of poor versus excellent execution. Journal of the Academy of Marketing Science, 28(3), 275-387.

Datta, P., Fraser, P., \& Lebcir, M. (2018). An investigation into the relationship between customer relationship marketing and customer retention: superstore retailing context in Bangladesh. Journal of Business and Retail Management Research (JBRMR), 13(2), 20-35

Dillman, D. (2000). Mail and internet surveys: The tailored design method (2nd ed.). New York, NY: Wiley Corporation.

Dwyer, R. (1987). Developing buyer-seller relationships. The Journal of Marketing, 51(2), 11-27.

Fornell, C., \& Larcker, D.F. (1981). Evaluating structural equation models with unobservable variables and measurement error. Journal of Marketing Research, 18(1), 39-50

Gronroos, C. (1997). Value-driven relational marketing: From products to resources and competencies. Journal of Marketing Management, 13(5), 407-420

Gronroos, C. (1999). Relationship marketing: Challenges for the organization. Journal of Business Research, 46(3), 327-335.

Grossman, R.P. (1999). Relational versus discrete exchanges: the role of trust and commitment in determining customer satisfaction. Journal of Marketing Management, 9(2), 47-58.

Gummesson, E. (2002). Total relationship marketing: Marketing management, relationship strategy, and CRM approaches for the network economy. Woburn, MA: Butterworth-Heinemann. 
Guo, W.W. (2010). Incorporating statistical and neural network approaches for student course satisfaction analysis and prediction. Expert Systems with Applications, 37(4), 3358-3365.

Hair, J.F., Hult, G.T.M., Ringle, C., \& Sarstedt, M. (2013). A primer on partial least squares structural equation modelling (PLS-SEM). Los Angeles: Sage Publications.

Hair, J.F., Hult, G.T.M., Ringle, C.M., \& Sarstedt, M. (2014). A primer on partial least squares structural equation modeling (PLS-SEM). California: SAGE Publications

Hair, J.F., Sarstedt, M., Ringle, C.M., \& Mena, J.A. (2012). An assessment of the use of partial least squares structural equation modeling in marketing research. Journal of the Academy of Marketing Science, 40(3), 414-433.

Hennig, T., Kevin, P., \& Gwinner, D. (2002). Understanding relationship marketing outcomes: An integration of relational benefits and relationship quality. Journal of Service Research, 42(2), 230-247.

Hennig-Thurau, T. (2004). Customer orientation of service employees its impact on customer satisfaction, commitment, and retention. International Journal of Service Industry Management, 15(5), 460-478

Henry, G.T. (1990). Practical sampling. London: Sage Publications.

Henseler, J., Ringle, C.M., \& Sarstedt, M. (2015). A new criterion for assessing discriminant validity in variance-based structural equation modeling. Journal of the Academy of Marketing Science, 43(1), 115-135. https:// doi.org/10.1007/s11747-014-0403-8

Kayaman, R., \& Arasli, H. (2007). Customer-based brand equity: Evidence from the hotel industry. Managing Service Quality, 17(1), 92-109

Kline, R.B. (2011). Principles and practice of structural equation modeling (3rd ed.). New York: The Guildford Press.

Knapp, M.L., \& Taylor, E.H. (1994). Commitment and its communication in romantic relationships. In A.L. Weber and J.H. Harvey (Eds.), Perspectives on close relationships (pp. 153-175). Boston: Allyn \& Bacon.

Kobayashi, F. (2011). Japanese high school students' television viewing and fast food consumption. Nutrition \& Food Science, 41(4), 242-248

Lu, Y., \& Seock, Y. (2008). The influence of grey consumers' service quality perception on satisfaction and store loyalty behavior. International Journal of Retail $\mathcal{E}$ Distribution Management 36(11):901-918

Lund, M. (1985). The development of investment and commitment scales for predicting continuity of personal relationships. Journal of Social and Personal Relationships, 2, 3-23.

Malhotra, N.K., \& Birks, D.F. (2006). Marketing research: An applied approach (2nd European ed.). Harlow: Financial Times, Prentice-Hall.

Mangano, J.A., \& Zhao, Y. (2013). Adult students' satisfaction at six two-year colleges. ERIC Database (EDI 180563)

Moller, K., \& Wilson, D. (Eds.). (1995). Business marketing: An interaction and network perspective. Boston: Kluwer Academic Publishers.

Morgan, M., \& Hunt, D. (1994). The commitment-trust theory of relationship marketing. Journal of Marketing, 58(7), 20-38 
Morgan, R.M. (2000). Relationship marketing and marketing strategy: The evolution of relationship marketing strategy within the organization. In J.N. Sheth and A. Parvatiyar (Eds.), Handbook of relationship marketing (pp. 481-504). Thousand Oaks, California: Sage Publications Inc.

O'Connell, W., \& Keenan, W. (1990). The shape of things to come. Sales and Marketing Management Journal, 1, 36-41.

Pizam, A., \& Ellis, T. (1999). Customer satisfaction and its measurement in hospitality enterprises. International Journal of Contemporary Hospitality Management, 11, 326339. http://dx.doi.org/10.1108/09596119910293231

Reichheld, F.F., \& Kenny, D.W. (1990). The hidden advantages of customer retention. Journal of Retail Banking, 12(4), 19-23.

Rempel, J.K., Holmes, J.G., \& Zanna, M.P. (1985). Trust in Close Relationships. Journal of Personality and Social Psychology, 49(1), 95-112

Rodriguez, C.M., \& Wilson, D.T. (2002). Relationship bonding and trust as a foundation for commitment in U.S.-Mexican strategic alliances: A structural equation modeling approach. Journal of International Marketing, 10(4), 53-76.

Rootman, C., Tait, M., \& Sharp, G. (2011). Relationship marketing and customer retention lessons for South African banks. Southern African Business Review, 15(3), 184-206

Schurr, P.H., \& Ozanne, J.L. (1985). Influence on exchange processes: Buyers' preconceptions of a seller's trustworthiness and bargaining toughness. Journal of Consumer Research, 11(4), 939-953

Shantanu, D. (2005). Sustained competitive customer retention: The role of learning and governance (Master Dissertation). University of Southern California.

Sheth, J.N., \& Parvatiyar, A. (1995). The evolution of relationship marketing. International Business Review, 4(4), 397-418

Sheth, J.N., \& Parvatiyar, A. (2000). The evolution of relationship marketing: Handbook of relationship marketing. Thousand Oaks: Sage Publication.

Storbacka, K., Strandvik, T., \& Gronroos, C. (1994). Managing customer relationships for profit: The dynamics of relationship quality. International Journal of Service Industry Management, 5(5), 21-38

Tikkanen, H., \& Alajoutsijarvi, K. (2002). Customer satisfaction in industrial markets: Opening up the concept. Journal of Business \& Industrial Marketing, 17(1), 25-42. https://doi. org/10.1108/08858620210415181

Weinstein, A., \& Johnson, N. (2003). Customer retention: A usage segmentation and customer value. Boston, MA: Harvard Business School Press.

Wetzels, M., Ruyter, K.D., \& Birgelen, M.V. (1998). Marketing Service Relationships: The Role of Commitment. Journal of Business \& Industrial Marketing, 13(4/5), 406-423

Wiele, T.V.D., Boselie, P., \& Hesselink, M. (2002). Empirical evidence for the relation between customer satisfaction and business performance. Journal of Service Theory and Practice, 12(3), 184-193

Williams, P., \& Naumann, E. (2011). Customer satisfaction and business performance: a firmlevel analysis. Journal of Services Marketing, 25(1), 20-32

Wilson, D.T. (1995). An integrated model of buyer-seller relationships. Journal of the Academy of Marketing Science, 23(4), 335-345. 